\title{
RNA editing in the Wilms' tumor susceptibility gene, WT1
}

\author{
Prem Mohini Sharma, ${ }^{1}$ Marianne Bowman, ${ }^{1}$ Stephen L. Madden, ${ }^{2}$ Frank J. Rauscher III, ${ }^{2}$ \\ and Saraswati Sukumar ${ }^{1,3}$ \\ ${ }^{1}$ The Salk Institute for Biological Studies, La Jolla, California 92037 USA, ${ }^{2}$ The Wistar Institute of Anatomy and Biology, \\ Philadelphia, Pennsylvania 19104 USA
}

\begin{abstract}
Rat kidney WT1 cDNAs contain either a thymidine or a cytosine residue at position 839. Genomic WT1 DNA contains only $\mathrm{T}^{839}$. To explain these results, we propose the WT1 transcript undergoes RNA editing in which $\mathrm{U}^{839}$ is converted to $C$, resulting in the replacement of leucine 280 in WT1 by proline. RNA editing at the same nucleotide was observed in WT1 cDNAs from human testis. In functional assays, the WT1-leucine ${ }^{280}$ polypeptide repressed the EGR-1 promoter in in vitro assays $\sim 30 \%$ more efficiently than WT1-proline. Edited WT1- ${ }^{839}$ mRNA was barely detectable in neonatal kidney, whereas adult rat kidneys contained both $U^{839}$ and $\mathrm{C}^{839}$-WT1 mRNA, suggesting a role for the two protein isoforms in growth and differentiation.
\end{abstract}

[Key Words: RNA editing; WT1; rat; human; developmental regulation]

Received November 5, 1993; revised version accepted February 1, 1994.

Wilms' tumor (WT) or nephroblastoma, a common pediatric, solid malignancy, accounts for $8 \%$ of childhood cancers. It occurs in both sporadic and familial forms (Haber and Buckler 1992; Haber and Housman 1992; Slater and Mannen 1992). There is considerable heterogeneity in the pathology of WTs, and several genes have been implicated in its etiology (Haber and Buckler 1992; Haber and Housman 1992; Slater and Mannen 1992). One of the genes, WTl, located on human chromosome $11 \mathrm{pl}$, is categorized as a tumor susceptibility gene for WT, as the loss of these sequences is associated with the development of childhood malignancies of the kidney. The complete cDNA sequence and the intron-exon organization of the WT1 gene have been deduced (Call et al. 1990; Gessler et al. 1990; Sharma et al. 1992). The WT1 gene contains 10 exons spanning $50 \mathrm{~kb}$ of DNA (Gessler et al. 1990; Haber et al. 1991), which is expressed as a 3.0-kb mRNA in the rat (Sharma et al. 1992). The open reading frame of WT1 mRNA is 1725,1719 , and 1576 nucleotides in human, mouse, and rat respectively, and encodes a zinc finger protein of $52-54 \mathrm{kD}$ with four zinc fingers $(\mathrm{Zfs})$, which is expressed at high levels during kidney development. At least four different WT1 mRNAs are expressed, which reflect the presence or absence of an alternatively spliced exon 5 , and three codons in exon 9 (Pelletier et al. 1991). These several mRNAs generate proteins with altered DNA-binding specificities predictive of distinct physiological roles for each protein (Madden et al. 1991; Bickmore et al. 1992). The alternative splice that is most abundant in the kidney contains 17 amino acids encoded by a separate exon

${ }^{3}$ Corresponding author.
5 , in the region proximal to the zinc finger domain, and 3 amino acids (lysine, threonine, and serine) between the third and the fourth zinc fingers. The least common is the transcript lacking both splices (Haber et al. 1991; P. Sharma et al., unpubl.). WT1 acts as a transcriptional regulator, a function consistent with the presence of four $\mathrm{ZF}$ motifs in the carboxy-terminal region (Call et al. 1990; Gessler et al. 1990) and a negatively charged proline/glutamine-rich trans-regulatory domain (Mitchell and Tjian 1989) at the amino terminus. The four contiguous zinc fingers of the cysteine-histidine $(\mathrm{C} 2 \mathrm{H} 2)$ class recognize and bind to the same DNA sequences $\left(5^{\prime}\right.$ GCGGGGGCG-3') as the early growth response-1 (EGR1) gene product (Rauscher et al. 1990). Other genomic sequences, to which the alternately spliced forms of WT1 protein bind, have been identified (Bickmore et al. 1992). Although DNA binding is mediated by the zinc finger domain, the amino-terminal domain of the WTl protein functions as a repressor of transcription in transient transfection assays utilizing the promoter sequences of the EGR-1 (Madden et al. 1991), platelet-derived growth factor-A chain (PDGF-A) (Gashler et al. 1992; Wang et al. 1992), insulin-like growth factor-2 (IGF-2) (Madden et al. 1991), and insulin-like growth factor-1 receptor (IGF-1R) (Werner et al. 1993) genes. These studies reinforced the anticipated function of WTl as a tumor suppressor protein, targeting and repressing, specifically, positive regulators of cell growth. However, WT1 may perform dual functions, as a transcriptional activator as well as a repressor. Recently, Wang and colleagues (Wang et al. 1993) performing experiments with the minimal promoter sequences of the PDGF-A chain gene, have provided evidence that the amino-terminal 
region of WT1 contains separate regulatory domains that function either to activate or suppress transcription.

In the course of sequencing cDNAs for WT1 in rats, we observed two alternate forms of cDNAs, as judged by sequence differences at nucleotide 839 . One form contains CTC, coding for leucine 280, and the other form contains CCC, encoding proline 280 (Sharma et al. 1992). The data in this paper show that this difference occurs by RNA editing. This RNA editing event is developmentally regulated in rat kidney and testis. The importance of these variant RNAs is underscored by the fact that they are evolutionarily conserved between rat and human. Furthermore, the Leu/Pro dimorphism affects the transcription repression function of the WT1 protein. Our results suggest that RNA editing in WT1 adds a new dimension to developmental stage-specific functions of the WTl protein.

\section{Results}

Single-stranded conformation polymorphism, restriction cleavage, and sequencing analyses of PCR-amplified products reveal that WT1 $c D N A$, but not genomic DNA, contains either $a T$ or $a C$ at nucleotide 839

On sequencing several cDNA clones from a rat testis library, either a $\mathrm{T}$ or a $\mathrm{C}$ residue was found at nucleotide 839 of rat WT1 (Sharma et al. 1992). This change results in the loss of a Mnll restriction cleavage site. To determine whether the $\mathrm{T} / \mathrm{C}$ difference at 839 is a genetic polymorphism, we examined DNA and RNA from Sprague-
Dawley rats. We amplified the region containing the $\mathrm{T} \rightarrow \mathrm{C}$ conversion, in genomic DNA extracted from several pairs of normal and tumorous kidneys, as well as kidneys from six untreated rats by PCR. The PCR products were screened for the presence of sequence variants by digestion with MnlI and by single-stranded conformation polymorphism (SSCP) (Orita et al. 1989a,b) analysis. On digestion with MnlI, the $\mathrm{T}^{839}$ yields $52-, 27-$, and 13-bp fragments. Replacement of the $T$ with $C^{839}$ results in loss of one of the MnlI restriction sites, yielding 79 and 13-bp fragments instead. SSCP analysis identifies the base change in the WT1 DNA as shifts in electrophoretic mobility of single-stranded DNA on nondenaturing gels. The plus and minus strands of DNA carrying the $T / A^{839}$ migrate slower than the ones carrying $\mathrm{C} / \mathrm{G}^{839}$.

The results of our analyses were unexpected. None of the 26 genomic DNA samples showed the bands diag. nostic of absence of the MnlI site or bands with altered gel migration reflective of the presence of a polymorphic nucleotide 839. cDNA samples from several of the same tissues had previously been positive in both assays (data not shown). The results of a representative SSCP experiment, where the migration of single-stranded exon 6 DNA and cDNA derived from five rat tissues (three normal tissues and two kidney tumors), and an immortalized rat embryo fibroblast cell line (Rat 2) is compared, are shown in Figure 1A. Of the six cDNA/genomic DNA pairs, mobility shifts were observed in cDNA-derived PCR fragments from Rat 2 cell line, a carcinogen-induced kidney tumor, 1166-1, and adult kidney. No shifts were observed in fragments from the kidney tumor 19728 , adult liver, and newborn kidney. No mobility shifts

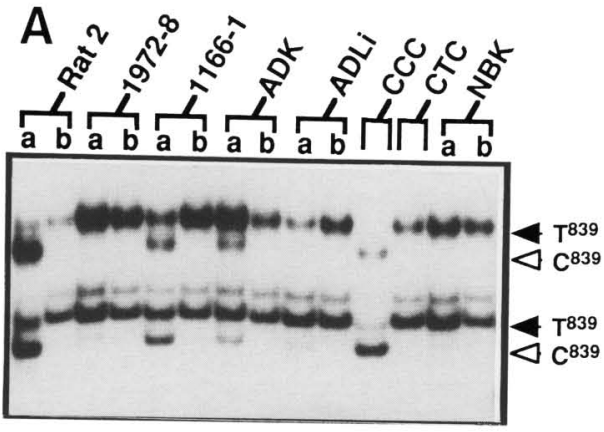

exon 6 SSCP
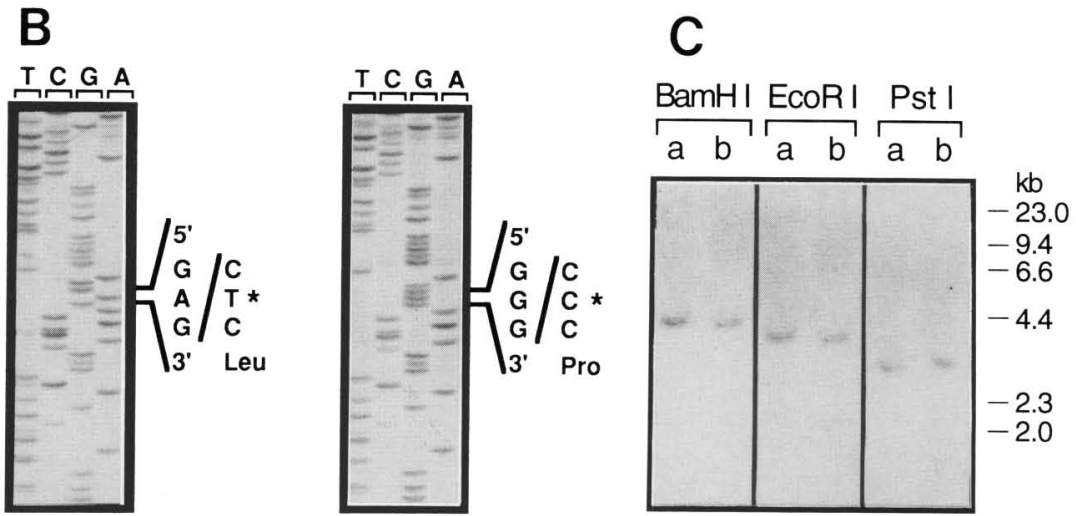

Figure 1. $(A)$ The $\mathrm{T}^{839} \rightarrow \mathrm{C}$ conversion occurs in the WT1 transcript but is absent in the WTl gene of both normal and tumor tissues. SSCP analysis of RT-PCR-amplified WT1 cDNA and DNA pairs in the region of exon 6 from Rat 2 cells, NMU-induced kidney tumors, 1972-8 and 1166-1, adult kidney (ADK), adult liver (ADLi), and newborn kidney (NBK). The ${ }^{32}$ P-labeled, PCR-generated 92-bp DNA fragments (exon 6, using 5451 and 5449 primers) from cDNA $(a)$ and DNA $(b)$ were electrophoresed under nondenaturing conditions as described in Materials and methods. Plasmid DNA containing cloned B2 cDNA fragments with either a $\mathrm{T}(\mathrm{CTC})$ or $\mathrm{C}(\mathrm{CCC})$ at nucleotide 839 served as source of controls for PCR of exon 6 and mobility shifts in PCR-SSCP. $(B)$ The nucleotide sequence of the adult kidney DNA (left) and cDNA (right) in the region of exon 6 showing the T $\rightarrow \mathrm{C}$ substitution at position 839 in the cDNA. The single-base change is marked by an asterisk $\left({ }^{*}\right)$ and has been confirmed by sequencing the complementary strand. $(C)$ Southern analysis of WT1 sequences in normal rat kidney. Genomic DNA $(15 \mu \mathrm{g})$ cut with BamHI, EcoRI, and PstI was subjected to electrophoresis through $0.8 \%$ agarose gels, and the Southern blot was probed with a randomly ${ }^{32} \mathrm{P}$-labeled, 92-bp, exon 6-specific (nucleotide 795-887) fragment of WT1. (Lane $a$ ) Newborn kidney; (lane $b$ ) adult kidney. The molecular size markers ( $\lambda$, HindIII fragments) are shown at right. 
were observed in the WT1 fragments of any of six tissue genomic DNA samples. PCR-amplified DNA and cDNA fragments of WT1 from the six tissues were subjected to cloning and sequencing. Sequence determination from at least 10 clones from each of the tissues verified the source of the mobility shifts observed in Figure 1A. A thymidine residue was found at position 839 in all of the DNA-derived clones, whereas either a thymidine or a cytosine was observed at the same position in the cDNA clones derived from the tissues eliciting mobility shifts in SSCP analyses (Fig. 1B). Additional sequencing of WT1 from the cDNA and genomic DNA clones derived from normal rat lung, liver, and testes showed that their genomic DNAs contained only $\mathrm{T}^{839}$, whereas the $\mathrm{cD}$ NAs contained $\mathrm{T}^{839}, \mathrm{C}^{839}$ or a mixture of both clones (data not shown). These data show that genomic DNA for exon 6 of the rat WT1 gene contains the coding sequence for leucine (CTC) at codon 280 , but not for proline $(C C C)$, even in tissues in which reverse transcriptase-polymerase chain reaction (RT-PCR) products show the presence of both CUC and CCC codons.

To date, there is no published report of a pseudogene for WT1. However, to formally rule out the contribution of a possible rat WT1 pseudogene, lacking introns, to the PCR product, we repeated the DNA amplification of exon 6 of WT1 using intron-specific primers. Although the fragment sizes were different, results identical to those using exon/exon primers were obtained by both MnII and SSCP assays, that is, only a T was present at nucleotide 839 (data not shown). Our attempts at amplifying WT1 gene sequences by PCR, across exons 5,6 , and 7 (intron sizes 4-8 kb), priming off the exonic sequences yielded no product. An intronless WT1 pseudogene, using this primer combination, would have yielded a 277 bp fragment. Additionally, we were successful in amplifying WT1 DNA exons 8, 9, and 10 across their considerably smaller sized (1-2 kb) introns. Again, the expected size fragments were generated, but none indicative of the presence of a WT1 pseudogene were seen. This preliminary evidence argues against the existence of an intron- less WT1 pseudogene in the rat genome. Also, Southern blot analysis of DNA digested with BamHI, BglII, EcoRI, or PstI, from several rat tissues using $3^{\prime}$, middle, and $5^{\prime}$ fragments of WT1 cDNA, full-length cDNA, or an exon 6-specific probe (Fig. 1C) failed to reveal any unexpected genomic fragments. It is clear, however, that if a rat WT1 pseudogene exists, with or without introns, it also contains a $\mathrm{T}$ at nucleotide 839 .

\section{Allele specific oligonucleotide hybridization $(A S O H)$ assays show that the genomic sequence of WT1 has only $T$ at nucleotide 839}

Further evidence in support of RNA editing at nucleotide 839 of WT1 was sought. A Southern blot was prepared from the PCR-generated exon 6 sequences of both WT1 DNA and cDNA from several normal rat tissues fractionated on native polyacrylamide gels. Differential hybridization was carried out using the 20-mer synthetic oligonucleotide probes specific for either $\mathrm{T}$ or $\mathrm{C}$ at position 839 as described in Materials and methods. On washing the blots at $1^{\circ} \mathrm{C}$ below the melting temperature of the oligonucleotide probes, only the T-specific oligonucleotide was found to remain bound to the DNA fragment amplified from the genomic DNA of each of the rat tissues analyzed (Fig. 2). In contrast, the cDNA samples from adult kidneys (ADK1, ADK2), and adult lung (ADL) hybridize to both the $\mathrm{C}$ - and T-specific probes, whereas Rat 2 cDNAs hybridize only to the C-specific probe. These results add further support to the hypothesis that genomic DNA has only $T$ at nucleotide 839 but that the expressed mRNA can contain either a $U$ or a $C$. These results were confirmed by nucleotide sequencing after cloning the 102-bp PCR-generated fragments into the vector pT7Blue. On sequencing at least 10 clones containing WT1 fragments from each tissue, $\mathrm{C}^{839}$ was observed in $30 \%$ (in tumor $1166-1$ and adult kidney) to $90 \%$ (in Rat 2 cells) of the clones, whereas in tumor 1972-8, adult liver, and newborn kidney, only the $\mathrm{WT} 1-\mathrm{T}^{839}$ was seen. Thus, the number of the $\mathrm{C}$ or $\mathrm{T}$ clones observed by

Figure 2. Hybridization of allele-specific oligonucleotides to determine the presence and distribution of $T^{839}-$ or $C^{839}-W T 1$ in cDNA and DNAs of various rat tissues. Twenty microliters of the reaction mix containing PCR-amplified fragments (primers 5451 and 5392) of WT1 cDNA and genomic DNA pairs from Rat 2 cells, newborn (NBK) and adult rat kidneys (ADK1 and ADK2), and adult rat lung $(\mathrm{ADL})$ was electrophoresed in a $10 \%$ native polyacrylamide gel, stained with ethidium bromide to visualize the PCR product $(A)$, transferred to a nylon membrane (Nytran, Schleicher \& Schuell) and $(B)$ hybridized to ${ }^{32} \mathrm{P}$-radiolabeled $\mathrm{CT}^{839} \mathrm{C}$ oligonucleotide (primer 5495). After exposure to $\mathrm{X}$-ray film for $4 \mathrm{hr}$ at $-70^{\circ} \mathrm{C}$, the probe was

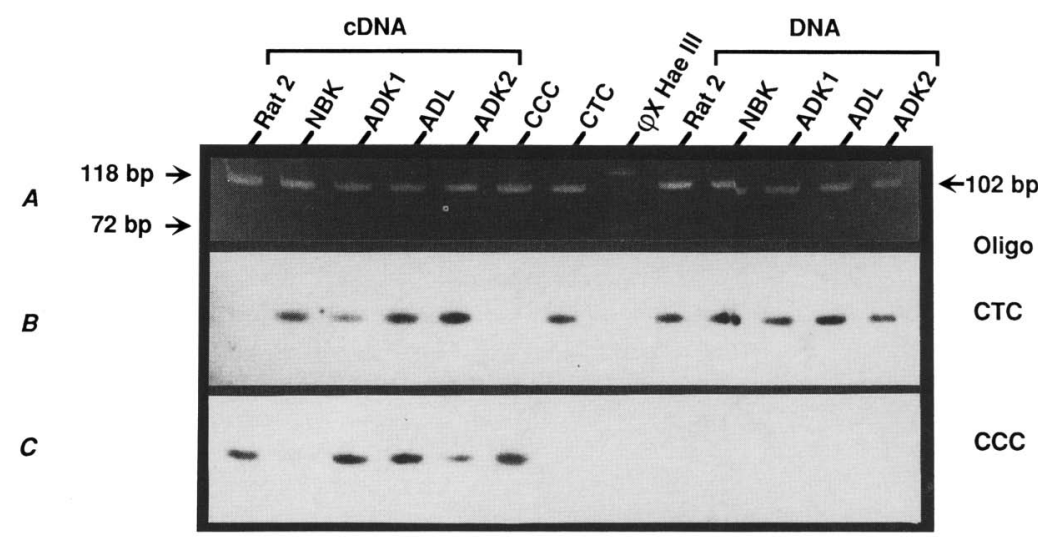
removed completely from the blot and $\mathrm{CC}^{839} \mathrm{C}$ allele-specific probe (primer 5496) was used for hybridization $(C)$. Plasmid DNA containing cloned B2 cDNA fragments with either a T (CTC) or C (CCC) at nucleotide 839 served as source of controls. The sizes of the coelectrophoresed DNA fragments of $H a e I I I$ cleaved $\phi_{X}$ DNA are given at left; the size of the PCR product is indicated at right. 
nucleotide sequencing was fairly reflective of the relative intensity of the shifted bands observed in SSCP and to the results of the ASOH analysis.

\section{The WT1 transcript sequence is not altered by $R T$ or Taq polymerase enzymes}

To examine the possibility that the $\mathrm{T}$ and $\mathrm{C}$ residues observed interchangeably in WT1 mRNA are attributable to the presence of specific sequences around codon 280 that might promote misincorporation of $C$ residues in place of $\mathrm{T}$ residues by Moloney murine leukemia virus (MMLV), RT or Taq DNA polymerase, two different approaches were followed. First, the MMLV enzyme was replaced by avian myeloblastosis virus (AMV) RT in the reverse transcription step. Our concern that the Taq polymerase might be introducing this change preferentially was addressed by performing the PCR amplification step using high-fidelity DNA polymerases from the hyperthermophilic archaebacteria Pyrococcus furiosus (Pfu polymerase) and Thermococcus litoralis (Vent polymerase). Identical SSCP and nucleotide sequencing results were obtained, irrespective of the enzyme used. Use of either of the two RTs in combination with one of the three DNA polymerases did not affect the outcome of the experiment (data not shown).

The second approach was to perform a transcript-mixing experiment by a loss of restriction site (LORS) analysis. The nucleotide editing change in WT1 mRNA $\left(T^{839} \rightarrow C^{839}\right)$ results in a loss of a restriction enzyme MnlI recognition sequence (CCTC) in the region of exon 6 . The presence or absence of the Mnll site in sequences encoded by exon 6 therefore serves as a diagnostic tool to distinguish between the $\mathrm{U}^{839}$ versus $\mathrm{C}^{839}$-containing mRNA in a variety of rat tissues and also across species, as the site is conserved in human, mouse, and rat WTl. For rat WT1, a PCR primer combination (5344 and 4585) generates a 277-bp fragment from the mRNAs containing the 51 nucleotides of the alternatively spliced exon 5 . The 277-bp $\mathrm{T}^{839}$-containing PCR product, upon restriction digestion with MnlI, generates several fragments, of which two are diagnostic fragments of sizes 114 and 27 $\mathrm{bp}$, whereas the $\mathrm{C}^{839}$-containing PCR product lacking this MnlI site, instead yields a 141-bp fragment (Fig. 3A).

Using the Mnl I assay, a direct test of the fidelity of the $\mathrm{RT}$ and Taq polymerase in copying the information from the mRNA was performed. We sought to mimic the mRNA in a cell. Each WT1 mRNA as in vitro-synthesized transcripts of 731-bp (nucleotides 196-927) containing either $\mathrm{U}$ or a $\mathrm{C}$ at nucleotide 839 , was mixed with total RNA from a human WT cell line G401, which lacks both copies of the WT1 gene. The mixture was reverse transcribed with MMLV-RT and PCR amplified with Taq polymerase. As predicted, Mnll digestion of the 277-bp PCR product of the $\mathrm{T}^{839}$-containing cDNA generated the 114- and 27-bp fragments, whereas digestion of the $\mathrm{C}^{839}$-containing cDNA yielded the 141-bp fragment (Fig. 3B). In vitro-transcribed mRNA, taken through the steps of RT and PCR alone or mixed with RNA from G401 cells gave results identical to the con-
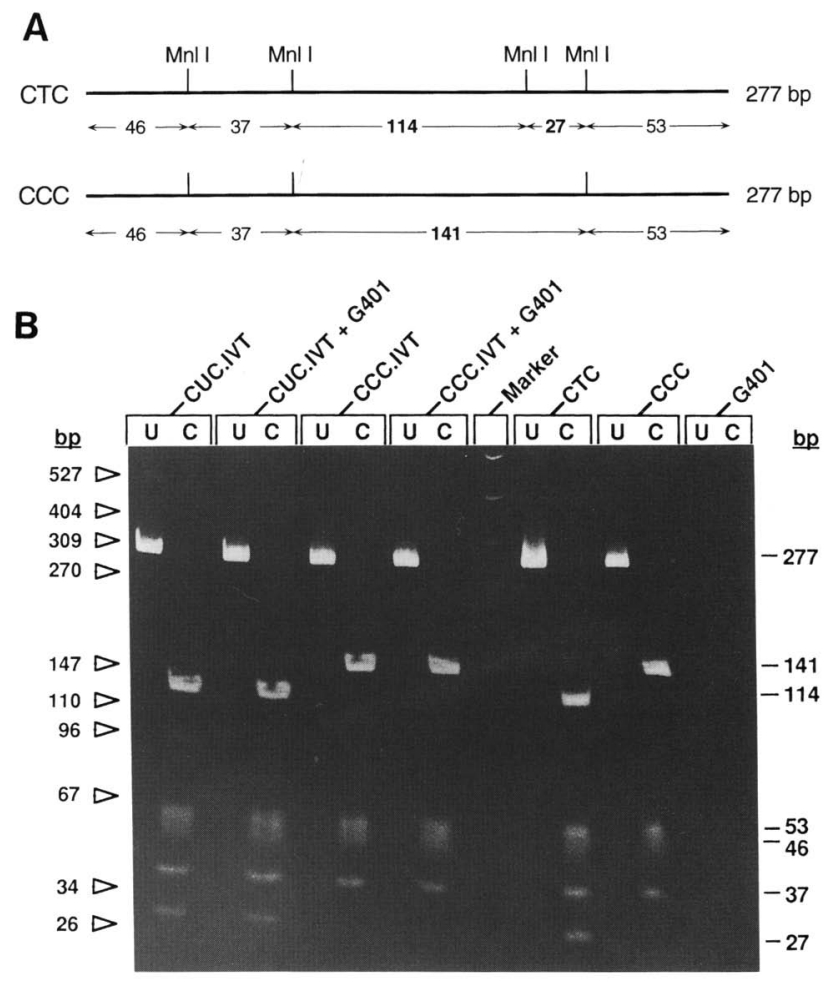

Figure 3. LORS analysis of RNA editing at codon 280 in rat WT1. (A) Diagrammatic representation of fragments generated in the edited and unedited transcripts of WT1 due to MnlI LORS. The sizes of the fragments (in bp) generated by digestion of the 277-bp PCR-amplified WT1 cDNAs, are shown. The diagnostic fragment sizes in the unedited and edited cDNAs are in boldface type. $(B)$ mRNA from in vitro-transcribed (IVT) B2 clones containing either $\mathrm{T}^{839}$ (CTC, IVT) or $\mathrm{C}^{839}$ (CCC, IVT) was mixed with 100 -fold excess of total RNA from G40I cells, a human Wilms' tumor cell line lacking both copies of the WT1 gene. Lane G401 is RNA from G401 cells with no added in vitro transcript. The samples were RT-PCR amplified to generate a 277-bp DNA fragment using specific primers as described in Materials and methods. Lanes labeled CTC and CCC are plasmid DNAs containing either a $\mathrm{T}$ or a $\mathrm{C}$ at nucleotide 839 , used as controls for PCR amplification and Mnll digestion. The sizes of the fragments generated following $M n l I$ restriction cleavage of the 277-bp PCR-amplified cDNA, visualized by ethidium bromide staining of the native $10 \%$ polyacrylamide gel, are shown at right (in bp). Fragments of pBR322 DNA digested with MspI (BRL) served as molecular mass markers.

trol plasmid DNAs. These experiments provided further proof that neither the RT, the Taq polymerase, exogenous factors present in total RNA, nor experimental artifacts are responsible for the generation of the $C^{839}$ transcript. The experiment was repeated using Drosophila melanogaster RNA as a carrier, with identical results (data not shown).

\section{Detection of the $T^{839}$ and $C^{839}$ in WT1 mRNA by RNase protection assays}

We used an RNase protection assay as a direct way of checking for the presence of the edited WTl transcript in 
unamplified RNA. A riboprobe encompassing the B2 area (nucleotide 196-927) of rat WT1 containing the alternate exon 5 in the vector pT7Blue, was hybridized with total RNA from newborn and adult rat kidney and subsequently digested with RNase A and RNase Tl. The $\mathrm{U}^{839}$-containing WT1 transcripts will protect the fulllength riboprobe of 731 nucleotides (Fig. 4a) or generate two fragments of 549 nucleotides plus 131 nucleotides (Fig.4c), depending on the presence or absence of alternate exon $5 \mid \pm 51$ nucleotides $\mid$. Hybrids containing the edited $\mathrm{C}^{839}$-containing mRNAs will be cleaved at the mismatched nucleotide 839 and will generate additional fragments: 643 and 88 nucleotides in the mRNAs containing exon 5 (Fig. 4b); $549+88+43$-nucleotide-long fragments in mRNAs lacking exon 5 (Fig. 4d). Although the smaller fragments were difficult to discern, the completely protected 731-bp fragment, diagnostic of $\mathrm{U}^{839}$, and the 643-bp fragment, diagnostic of the $\mathrm{C}^{839}$ forms of WT1 transcripts were clearly visible in the adult kidney RNA (Fig. 4). The presence of a 643-bp fragment generated by cleavage by RNase A at the C-U mismatch (Myers et al. 1985; Winter et al. 1985) in adult kidney RNA is indicative of the presence of the edited transcript in adult kidney. Approximately 10-fold lower levels of the 643-bp fragment were seen in the neonatal kidney.
Expression of edited forms of WT1 mRNA is developmentally regulated

In the case of apolipoprotein $\mathrm{B}(\mathrm{apoB})$ as well as the glutamate receptor (GluRB), the timing and site of preferential expression of the edited forms of RNA provided an indication of their putative functions (for review, see Chan 1993). Unedited forms of apoB mRNA (apoB100) are present in the liver, whereas the expression of the edited form (apoB48) is confined to the small intestine (Powell et al. 1987; Teng et al. 1990; Wu et al. 1990). The edited form of GluRB is the predominantly expressed mRNA during the early developmental stages (Burnashev et al. 1992a,b). The peaks of WT1 mRNA expression in the rat kidney follow a course that runs parallel with the gain of functional maturity. Thus, the peak of expression of WT1 mRNA in the kidney occurs during the first week after birth.

We sought to determine whether the expression of the edited and unedited forms of the WT1 mRNA are developmentally regulated as well. Figure 5 shows the PCRSSCP analysis of exon 6 sequences of rat WTI cDNAs from the kidneys of newborn and adult rats. The four samples of newborn rat kidney RNAs were obtained from pools of five to six kidneys from 2- to 5-day-old rats,
Figure 4. RNase protection analysis of WT1 across region of editing. $(a-d)$ Diagrammatic representation of the protected hybridization products among the different alternatively spliced and edited WT1 transcripts and the riboprobe. A 731-nucleotide antisense RNA radiolabeled probe (broken line with an asterisk) containing exon $5(\nabla)$ and $U^{839}$ was annealed to total RNA from newborn and adult rat kidney and the resulting RNA-RNA duplexes were treated with RNase A and RNase Tl. The sizes of the ${ }^{32} \mathrm{P}$-labeled RNA fragments protected from RNase digestion by different transcripts are indicated below the broken lines. (b) The sizes of the ${ }^{32} \mathrm{P}$-labeled MspI-digested pBR322 DNA fragments (M) are shown to the left of the gel; the sizes of the protected fragments are shown to the right of the gel. Total RNA $(50 \mu \mathrm{g})$ from newborn (NBK) or adult (ADK) rats was hybridized to the 731-nucleotide antisense rat WT1 riboprobe, digested with RNase $A$ and RNase T1. The protected fragments were resolved in a $6 \%$ urea-acrylamide sequencing gel and subjected to autoradiography. Appropriate tRNA $(50 \mu \mathrm{g})$ controls processed alongside the test RNAs and the undigested probe were loaded as indicated. For clarity, probe and marker lanes were derived from autoradiographs exposed for $1 \mathrm{hr}$, whereas the tRNA, ADK, and NBK lanes were overnight exposures of the same gel.

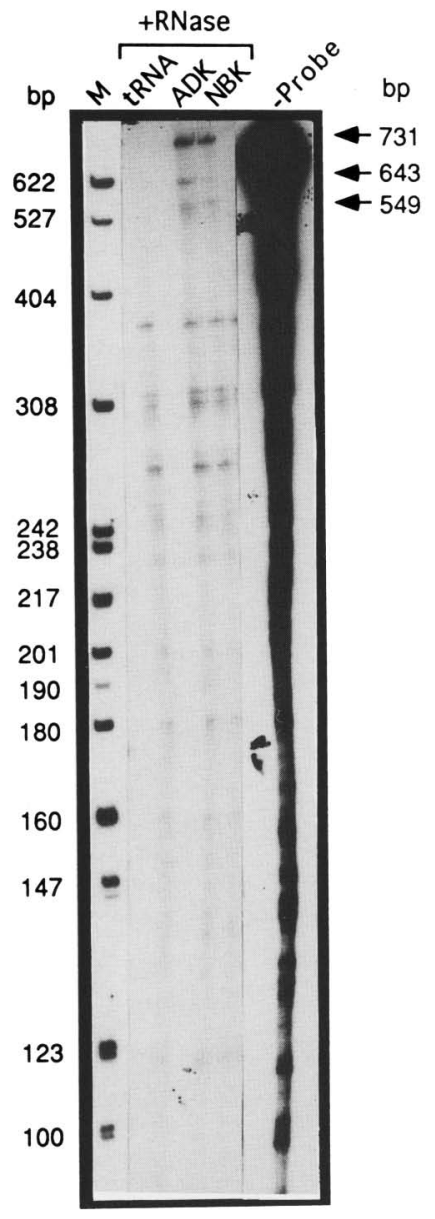

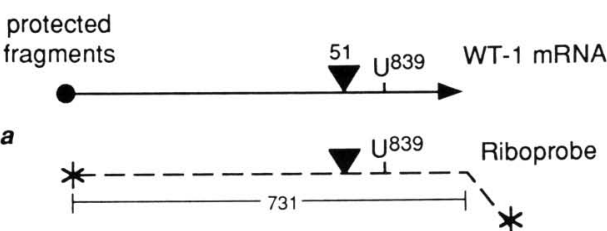

b
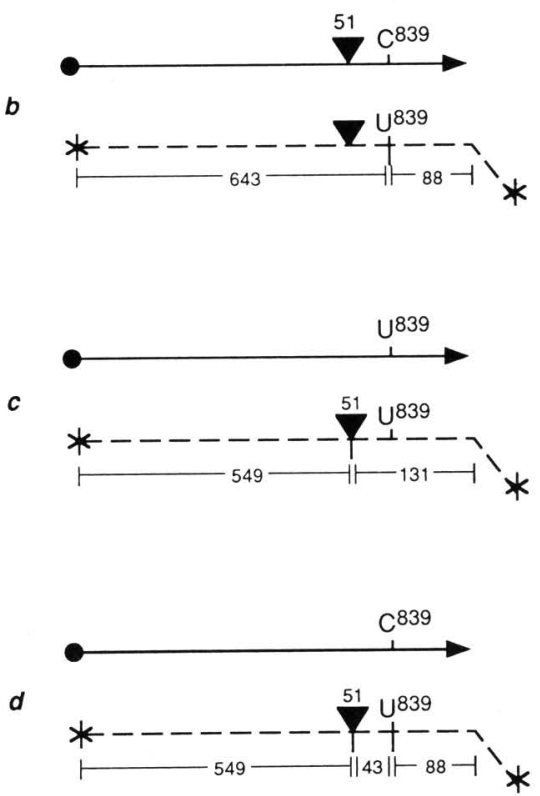


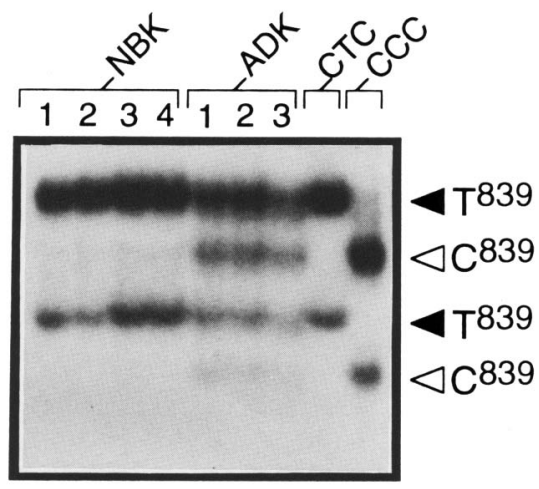

Figure 5. RNA editing of WT1 is developmentally regulated. cDNAs from four pools of newborn kidneys (NBK), each pool containing four to five individual kidneys from 2- to 4-day-old rats, and three adult kidneys (ADK) from rats aged 2 months were subjected to PCR-SSCP analysis. PCR primers 5451 and 5449 were used to generate a 92-bp fragment of exon 6. CCC and CTC are the controls for mobility of a $\mathrm{T}^{839}$ or a $\mathrm{C}^{839}$-containing cDNA derived from plasmids carrying the B2 insert of WT1. Densitometric analysis was done on autoradiographs using a flatbed scanner (Omnimedia XRS), and NIH Image 1.49 software.

and adult rat kidney RNA was obtained from single kidneys of individual 2-month-old rats. In the newborn kidney cDNAs, the 92-bp PCR-generated fragment gave a SSCP pattern consistent with the presence of CUC at codon 280 of the mRNA. Upon longer exposure however, trace levels of the CCC form of the mRNA was observed at this time of development indicating its low abundance. On the contrary, PCR fragments generated from cDNAs of adult kidneys show the appearance of bands with distinct mobility differences that are indicative of the presence of the CCC form of WT1, in addition to the CUC mRNA, at this stage (Fig. 5). The ratio of CUC/ CCC mRNAs varied from 1:0.5 to 1:0.4 in the adult rats. To confirm the results of the SSCP analysis, the PCR products were cloned and sequenced (data not shown). In the newborn kidney, no $\mathrm{C}^{839}$-containing clones were detected among the 20 sequenced clones, whereas adult kidney contained a mixture of $\mathrm{T}^{839}$ and $\mathrm{C}^{839}$ clones of WTl in varying ratios that corresponded to the band intensities seen in Figure 5. The results of the RNase protection assays clearly support these findings. The PRO (CCC) form of WT1 (643 nucleotides, RNase cleaved) was visible in the adult kidney, suggesting that the expression of the edited mRNA is developmentally regulated (Fig. 4). Clearly, there exists a developmental stage specificity for the editing phenomenon in kidney that also differs from tissue to tissue (P. Sharma, unpubl.) in the rat. However, we have not yet ruled out the possibility that the differences are caused by differential mRNA stability rather than by stage-specific mRNA editing.

\section{mRNA editing of WT1 is conserved between rat and human}

WT1 sequences exhibit a high degree of conservation at the amino acid level across different species. Based on the $>\mathbf{9 7 \%}$ homology between the rat and human amino acid sequences, we investigated the conservation of mRNA editing at nucleotide 1222 in human WT1 (Gessler et al. 1990). This position is the equivalent of nucleotide 839 in rat WT1 mRNA (Sharma et al. 1992). The rat WT1 is 1 amino acid, or 3 nucleotides, shorter than the human or mouse WT1 (Sharma et al. 1992). As a result, in human WT1 the edited nucleotide lies in codon 281 in the +51 -nucleotide mRNA splice form and codon 264 in the -51-nucleotide WT1 mRNA. Similar to rat WT1, nucleotide 1222 of the human WT1 cDNA clone LK15 (Gessler et al. 1990) is part of a conserved MnlI restriction cleavage site. We PCR-amplified WT1 fragments from cDNA libraries derived from adult testis and placenta mRNA. In the human testis cDNA library, both $\mathrm{T}$ and $\mathrm{C}^{1222}$ forms of the WT1 cDNA were observed by nucleotide sequencing across the edited nucleotide (Fig. 6). Again, to eliminate the possibility that human WT1 is polymorphic at this locus, exon 6 sequences were amplified from the DNA extracted from peripheral blood cells from 15 normal individuals and subjected to the SSCP assay, followed by nucleotide sequencing. Results of the sequencing analysis of the genomic WT1 fragments confirmed the presence of only CTC at codon 281 (data not shown), similar to other published sequences of human (Haber and Buckler 1992; Haber and Housman 1992) and rat.

\section{The PRO form of WT1 is more efficient} in transcriptional repression of EGR-1 than the LEU form

The WT1-LEU protein binds the EGR-1 consensus DNA sequence and has been shown to repress basal and EGR-
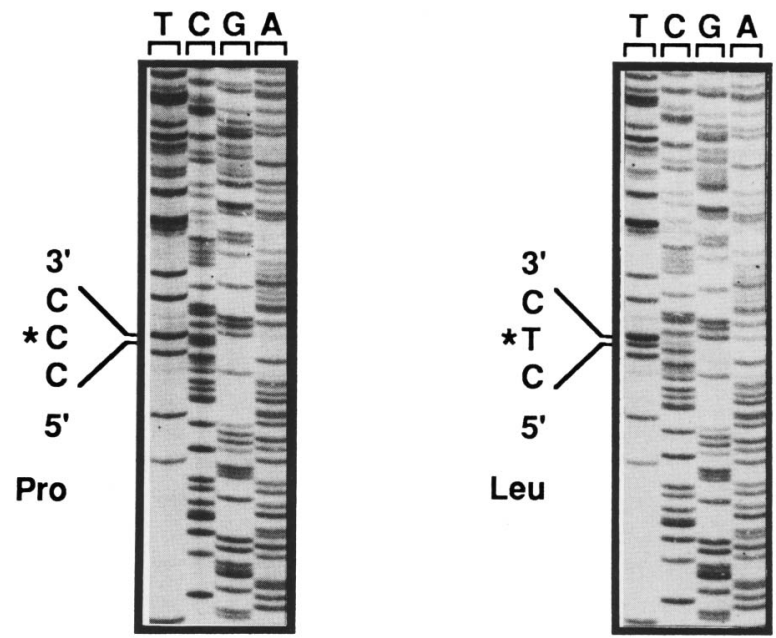

Figure 6. RNA editing of WTl gene is conserved in human. Nucleotide sequence of two PCR-derived cDNA clones from an adult human testes library in $5^{\prime} \rightarrow 3^{\prime}$ direction showing the $\mathrm{T} \rightarrow \mathrm{C}$ substitution at position 1222 with respect to the human WT1, LK15 clone. The single-base change is marked by an asterisk (*). 
1-induced transcription in transient transfection assays with synthetic promoter constructs (Madden et al. 1991). To determine the biological function of the edited WT1 protein, NIH-3T3 fibroblasts were cotransfected with increasing amounts $(2.5,5.0,10.0$, and $15.0 \mu \mathrm{g})$ of expression vector containing the full-length coding region (-51-bp alternate exon 5) of human WT1 (Call et al. 1990 ) in a cytomegalovirus (CMV)-driven plasmid corresponding to either the unedited (CB6-WT1, LEU-264) or the edited (CB6-WT1, PRO-264) forms with $1.0 \mu \mathrm{g}$ of pEGR-1.1.2-chloramphenicol acetyltransferase (CAT) reporter plasmid containing $1.0 \mathrm{~kb}$ of the murine EGR-1 promoter (Madden et al. 1991). As seen in Figure 7, A and $B$, efficient repression of the high basal levels of transcriptional activity of pEGR-1.1.2-CAT in NIH-3T3 cells grown in $10 \%$ serum was seen with increasing amounts of the cotransfected plasmid, CB6-WT1, LEU264. Side-by-side comparison of either CB6-WT1, LEU264 and CB6-WT1, PRO-264 showed that the PRO-264 form was $25-30 \%$ less efficient at repression at each of the concentrations tested (Fig. 7A,B). We conclude that WT1-PRO has a deleterious effect on the repression function of the WT1-LEU protein. To ascertain whether an equally efficient expression of the LEU and PRO forms of the protein occurs in mammalian cells using the CMV-driven vectors, the CB6-WT1, LEU-264 and CB6-WT1, PRO-264 plasmids were transfected into COS-1 cells. The $\left.{ }^{35} \mathrm{~S}\right]$ methionine-labeled protein products were immunoprecipitated with anti-WTZF antibodies (Morris et al. 1991) and resolved on an SDS-polyacrylamide gel (Fig. $7 \mathrm{C}$ ). The $52-\mathrm{kD}$ WT1 proteins, which comigrated with the WTl protein produced in an in vitro translation reaction (not shown), were expressed equally efficiently in COS-1 cells. We assume that this is also the case when these proteins are expressed in the NIH$3 \mathrm{~T} 3$ cells used for the transcription assays.

\section{Discussion}

Our results are strongly suggestive of a tissue-specific, temporally controlled, functionally important, editing of RNA from the WT1 locus. This editing involves a $\mathrm{U} \rightarrow \mathrm{C}$ conversion resulting in the production of proteins containing leucine (CUC) or proline $(\mathrm{CCC})$ at amino acid position 280 . The developmental and temporal control, as well as the differences in the test of WT1 function, suggest the possibility that the observed differences are biologically meaningful.

The origin of two WT1 transcripts differing by a single nucleotide reported here could be explained by differential splicing of either a CTC- or a CCC-containing exon 6 in the WTl gene or by the presence of two WTl genes. Both of these possibilities have been eliminated by use of exon-flanking primers for the amplification of exon 6 and intragenic probes that identify single bands on genomic Southern analysis (Fig. 1C), by fine restriction mapping of cloned genomic DNA, and by determining the nucleotide sequence of the gene (P. Sharma et al., unpubl.). Our results indicate that there is no duplication of exon 6, which contains the CTC codon, and no direct repeats that might represent alternative exons. Furthermore, both sequencing and differential oligonucleotide
$\boldsymbol{A}$

Expression vector:

WT1, LEU-264

gNA:

WT1, PRO-264
$B$
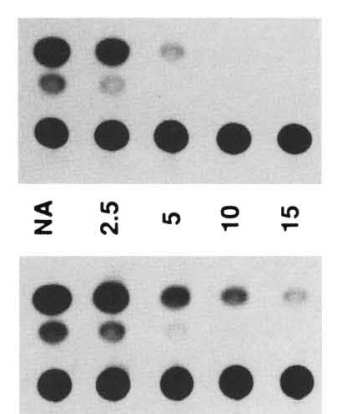

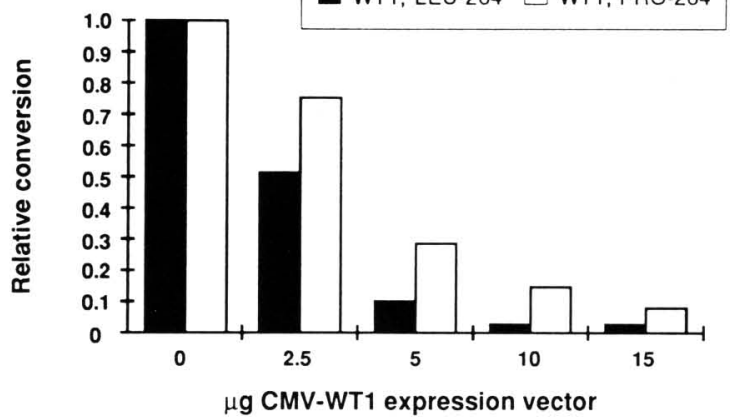

壱

c $\bar{\xi} \mathrm{kD}$

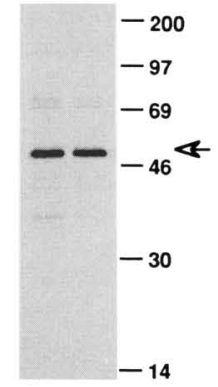

Figure 7. Transcription repression activity of the WT1 derivatives. (A) Calcium phosphate cotransfection of human WT1, LEU-264, or PRO-264 expression plasmid with the pEgr-1.1.2-CAT reporter plasmid was performed in NIH-3T3 cells, and CAT activity was determined as described previously (Gorman et al. 1982; Madden et al. 1991). One microgram of pEgr-1.1.2-CAT and the indicated amounts of expression plasmids were used in each transfection. (NA) No addition of WTl-expressing plasmid. All transfections contained equal amounts of the CMV expression plasmid $\mathrm{CB}^{+}$and $2 \mu \mathrm{g}$ each of a CMV- $\beta$-galactosidase internal standard plasmid (pON260; Spaete and Mocarski 1985) and high-molecular-weight calf thymus DNA (BMB). Transfections were repeated twice in duplicate and with two independent WT1, PRO-264 isolates with results similar to the data shown. TLC plates were quantified by scanning with an Ambis densitometer. $(B)$ Bar graph representing the results of $A$. $(C)$ Expression analysis of WT1 derivatives: CMV-driven expression plasmid CB6-WT1, LEU-264, and CB6-WT1, PRO-264 were transfected into COS-1 cells by the DEAEdextran method as described previously (Morris et al. 1991). Cells were labeled with $\left[{ }^{35} \mathrm{~S}\right]$ methionine and subjected to immunoprecipitation analysis with anti-WTZF antisera as described previously (Morris et al. 1991). The arrow show the 52-kD, full-length WT1 protein. $\mathrm{CB}^{+}$transfectants as well as preimmune antisera controls showed no detectable protein at $52 \mathrm{kD}$ (data not shown). 
hybridization of genomic DNA show that no CCC codon is present in the rat WTl gene.

Our data rule out the following trivial mechanisms for generating the variant RNAs: (1) pseudogenes; (2) RT artifacts; (3) PCR artifacts. We have not yet ruled out misincorporation by RNA polymerase II.

We were not able to detect an intronless, rat WT1 pseudogene. The MnlI restriction cleavage site, diagnostic of $\mathrm{T}^{839}$ is not lost in DNA of $>50$ tissues examined from rats of three different strains, Sprague-Dawley, Fischer-344, and Buffalo/N (P. Sharma et al., unpubl.). In the absence of gene duplication, alternate exon usage, or a pseudogene, the conclusion must be that the WT1 CCC codon in mRNA arises as a result of co- or posttranscriptional RNA editing involving a single $T \rightarrow C$ substitution.

We were particularly concerned that misincorporation by one of the polymerases used in RT-PCR amplification of WT1 mRNA might give rise to this result. The polymerase activity of viral RTs exihibits no proofreading function and is notoriously error prone, misincorporating inappropriate nucleotides at frequencies in the range of 1 in $10^{-4}$ to $10^{-3}$ /Goff 1990; De La Torre et al. 1992|. However, WT1 cDNAs generated using either AMV or MMLV enzymes showed a $U$ or a $C$ nucleotide at position 839 of WTl at nearly equal frequencies from at least some RNA sources. When reconstruction experiments were conducted using synthetic sources of mRNAs, no evidence for misincorporation of nucleotides by the RTs due to any possible secondary structures in the mRNA sequences around the area of editing was found (Fig. 3). Thermostable Taq DNA polymerase is also known to create point mutations at a frequency of $\sim 1$ in $600 \mathrm{bp}$, PCR-amplified DNA fragments (Kunkel et al. 1987; Mattila et al. 1991). This plausible source of artifact in our observations was also ruled out by replacing Taq DNA polymerase with either Pfu DNA polymerase or Vent DNA polymerase, both of which possess $3^{\prime} \rightarrow 5^{\prime}$ proofreading exonuclease functions in addition to their $5^{\prime} \rightarrow 3^{\prime}$ DNA polymerase activities.

Several editing phenomena have been described over the past few years that result in the predetermined modification of the coding potential of certain genes (for review, see Cattaneo 1991; Wissinger et al. 1992; Chan 1993). A comparison of RNA editing in transcripts of $\operatorname{apoB}(C \rightarrow U)$, GluRB subunits $(A \rightarrow G)$, and cytochrome $b(\mathrm{C} \rightarrow \mathrm{U}$, rarely $\mathrm{U} \rightarrow \mathrm{C})$ locus of higher plants to that occurring in rat WT1 points to interesting parallels. In all three mammalian genes and the plant mitochondrial transcripts, a single-base substitution is observed between gene and transcript covering a large transcription unit, although additional edited sites have been observed both in the apoB and GluRB transcripts (Navaratnam et al. 1991; Kohler et al. 1993). Interestingly, in the cytochrome $b$ and the cytochrome oxidase subunit II transcripts of the higher plant, Oenothera berteriana, the nucleotide alteration changing a genomic thymidine to a cytidine in the mRNA sequence exactly parallels the rat WT1 editing phenomenon (Cattaneo 1991).

The tissue specificity of the editing process poses a key question as to how this specificity arises. In WT1 mRNA, 9 nucleotides preceding the $\mathrm{U} / \mathrm{C}^{839}$ and 33 following it are perfectly conserved between rat and mouse, whereas among rat, mouse, and human, 10 nucleotides surrounding the edited site are highly conserved, the 7 preceding it and the 3 following it. In a similar context, in apoB mRNA, 4 nucleotides preceding the $\mathrm{C} / \mathrm{U}$ and 18 following it are conserved among different species. Studies on sequence specificity of apoB mRNA editing by Shah et al. (1991) demonstrate that an 11-base sequence, 5 bases downstream to the $\mathrm{C}$, appears to be important. Mutations introduced in this region generally repress editing in vitro. Using apoB mRNA deletion and translocation mutants in an in vitro system, Backus and Smith (1991) determined that sequences $3^{\prime}$ of the edited site were absolutely required for editing, whereas specific sequences and bulk RNA 5' of the editing site were necessary for efficient editing. The presence of conserved sequences flanking the edited site in the WT1 mRNA provides a clue that a sequence specific mechanism may be playing a similar role in the WTl editing process. Work is in progress using short WTl minigene constructs spanning exon 6 as editing substrates in transfection experiments to study the specificity and the efficiency of this process. In addition, parallel experiments using full-length WT1 constructs are also being carried out because RNA editing could be coupled to splicing and/or polyadenylation (Lau et al. 1991).

The possible mechanism by which a uridine residue can be converted to a cytidine can be deduced based on the $\mathrm{U} \rightarrow \mathrm{C}$ transition as well as $\mathrm{C} \rightarrow \mathrm{U}$ editing in mitochondrial genes of a higher plant, O. berteriana (Schuster et al. 1990). The enzymes cytidine deaminase and CTP synthetase, which interconvert $U$ and $C$, catalyze both forward and backward reactions in the metabolism of nucleotides with high efficiencies, and they could be involved in the bidirectional editing in plant mitochondria. Investigation on the involvement of enzyme activities and the necessary specificity factors similar to the ones involved in known editing mechanisms in plants and mammals (Teng et al. 1993) will allow us to determine more conclusively the biochemical reactions and requirements of RNA editing in the WTl gene.

Although a small $(25-30 \%)$, but reproducible, reduction of the efficiency of transcription repression by WT1-PRO compared with WT1-LEU of the EGR-1 promoter was observed, the effects of the proline/leucine change on other promoters is likely to be more significant. The edited codon 280 lies within the region of WT1 that has been recently identified as the domain responsible for the transcription activation function of the WT1 protein on the PDGF-A chain promoter /Wang et al. 1993). It is likely that the PRO form is a more potent trans-activator than the LEU form. The transcription activation and repression activities of the edited form of the rat WT1 protein in its various alternative splice forms need to be investigated, using a variety of genes that are active in kidney development and function. Antipeptide antibodies directed against the region around residue 280 could distinguish the WT1-LEU 280 and 
PRO 280 forms and help us to determine their relative levels and the biological significance of the editing process in the WTl gene.

In conclusion, we have demonstrated that in rats and humans, the WT1 transcript undergoes mRNA editing resulting in two distinct WT1 proteins. We have also determined that in rats, RNA editing occurs in a large proportion of the WT1 mRNAs in kidney. The molecular mechanism for this developmentally regulated process will be the subject of future investigation.

\section{Materials and methods}

\section{Oligonucleotides}

The following oligonucleotides were synthesized on an Applied Biosystems DNA synthesizer. Nucleotide positions refer to rat WT1 mRNA sequence considering the initiator ATG as the first codon (Sharma et al. 1992): (4581) CCACCCCACTCCTTCATCAAA, 21-mer with $5^{\prime}$ end at nucleotide 196 of rat WT1; 44585) AAGAGTTGGGGCCACTCCAGATA, 23-mer with 5' end at nucleotide 927 of rat WT1; (5344) GGACGCCCTACAGCAGTGACAA, 22-mer with $5^{\prime}$ end at nucleotide 650 of rat WT1 and at nucleotide 1033 of human WT1, LK15 clone (Gessler et al. 1990); (5392) ctacCCTGAATGCCTCGGAAGACA, 24-mer with $5^{\prime}$ end at nucleotide 892 , with the lowercase letters being intron 7 sequences; (5451) CCACGGCACAGGGTACGAGA, 21-mer with $5^{\prime}$ end at nucleotide 795 of rat WT1; (5495) CCCATCCTCTGTGGTGC, 17-mer (CTC-leu) with $5^{\prime}$ end at nucleotide 832 and $\mathrm{T}$ at $839\left(T_{\mathrm{m}} 56^{\circ} \mathrm{C}\right) ;(5496)$ CCCATCCCCTGTGGTGC, 17-mer (CCC-pro) with $5^{\prime}$ end at nucleotide 832 and $\mathrm{C}$ at $839\left(T_{\mathrm{m}} 58^{\circ} \mathrm{C}\right) ;(5655)$ AAGAGTCGGGGCTACTCCAGG, 21-mer with $5^{\prime}$ end at nucleotide 1310 of LK15. Hum: GGCTCCGCAGGGGATGGGCGT, 21-mer with $5^{\prime}$ end at nucleotide 1232 of LK15. Oligonucleotides 4585, 5392, 5655, and Hum are complementary to rat and human WTI mRNA as indicated.

\section{PCR amplification, cloning, and sequencing of WT1 fragments}

Typically, each PCR-amplification cycle consisted of denaturation at $92^{\circ} \mathrm{C}$ for $1 \mathrm{~min}$, annealing at $56^{\circ} \mathrm{C}$ or $60^{\circ} \mathrm{C}$ for $1 \mathrm{~min}$ and extension at $72^{\circ} \mathrm{C}$ for $30 \mathrm{sec}$ for the small fragments, up to $1 \mathrm{~min}$ for fragments larger than $500 \mathrm{bp}$. Each $100-\mu \mathrm{l}$ reaction contained $500 \mathrm{ng}$ of genomic DNA or $10 \mathrm{ng}$ of plasmid DNA, and 2 units of Taq polymerase (Cetus). When Pfu polymerase (Stratagene) or Vent polymerase (NEB) was used, the reaction conditions specified by the manufacturers were followed. Four different PCR (Saiki et al. 1988) products generated using reverse-transcribed cDNAs and specific oligonucleotide pairs were cloned into plasmid vectors. First, a 731-bp fragment (B2: nucleotide 196-927), spanning exons $1-7$, was generated using primers 4581 and 4585. Second, a 277-bp rat WT1 fragment (nucleotides 650-927) was amplified using 5344 and 4585 as primers. Human sequences across a similar region (nucleotide 1033-1310 of LK15) were amplified with oligonucleotides 5344 and 5655 . Third, a 92-bp rat WT1 fragment (795-887) encompassing most of exon 6 sequences of rat WTl was generated using the primer combination 5451 and 5449. Fourth, a 102-bp DNA fragment containing the entire exon 6 of rat WT1 (795-892) was PCR amplified using an exon specific primer, 5451, and an exon-intron junction primer, 5392. The annealing temperatures for each set were determined individually. For the first set of oligonucleotides, $56^{\circ} \mathrm{C}$ was found to be the optimal annealing temperature. All of the other sets were annealed at $60^{\circ} \mathrm{C}$.

The PCR products were analyzed on $10 \%$ polyacrylamide gels, band-isolated, and subcloned into pT7Blue (Novagen) or the TA cloning vector (TA Cloning Systems) according to the manufacturer's instructions. Individual colonies were picked, and diagnostic PCR was performed on the bacterial lysate using the original primer pair used to generate the fragment, to verify the presence of the correct insert. Clones B2 and B2-277 bp were sequenced using either the 5451 or the 4585 primer. Sequencing was performed by using standard double-stranded sequencing reactions and Sequenase version 2.0 (U.S. Biochemical). Both strands were sequenced. Point mutations were detected often (at least 1 in 600 bases) in PCR amplification using Taq polymerase. Therefore, each cloning and sequencing experiment was repeated with at least two separate PCR reactions generated from two separate RTs. Smaller clones containing exon 6 were sequenced using vector primers (M13 or T7).

\section{PCR-SSCP analysis}

The B2 region of rat WT1 spanning exons $1-7$ (731 bp) and exon $6(92$ or $102 \mathrm{bp}$ ) were amplified independently by either the RT-based PCR method from mRNAs or by direct amplification of the DNA, using specific primers. For RNA-PCR, $2 \mu \mathrm{g}$ of total RNA was heated at $65^{\circ} \mathrm{C}$ for $5 \mathrm{~min}$ and then reverse transcribed using 200 units of MMLV RT (Bethesda Research Laboratories, $\mathrm{BRL}$ ) in $1 \times \mathrm{RT}$ buffer (BRL), $200 \mu \mathrm{M}$ deoxynucleotide $5^{\prime}$ triphosphate (dNTP), $10 \mu \mathrm{g} / \mathrm{ml}$ of random hexanucleotide primer (Pharmacia), $2 \mathrm{~mm}$ dithiothreitol, and 35 units of RNasin (Promega) in a total volume of $20 \mu \mathrm{l}$. cDNA was also prepared using AMV RT (U.S. Biochemical), with the following changes in the protocol. The reaction was done at $42^{\circ} \mathrm{C}$ for $1 \mathrm{hr}$, in RT buffer provided by the supplier using 10 units of AMV RT per reaction. One-fourth of the reverse transcription product (cDNA), or $50 \mathrm{ng}$ of genomic DNA, was amplified for SSCP analysis using the PCR reaction $\left(1 \mathrm{~min}\right.$ and $30 \mathrm{sec}$ at $92^{\circ} \mathrm{C}, 1 \mathrm{~min}$ at annealing temperature, and $1 \mathrm{~min}$ at $72^{\circ} \mathrm{C}$ for $30 \mathrm{cycles}$, followed by $5 \mathrm{~min}$ at $72^{\circ} \mathrm{C}$ ) with the primer pairs listed above for the corresponding fragment. The reaction mixture was made up of the following: $0.5 \mathrm{~mm}$ each primer, $70 \mathrm{mM}$ of each $\mathrm{dNTP}, 10$ $\mathrm{mm}$ Tris $(\mathrm{pH} 8.3), 50 \mathrm{~mm} \mathrm{KCl}, 1.5 \mathrm{mM} \mathrm{MgCl}_{2}, 0.01 \%$ gelatin, 0.25 units of $T a q$ polymerase (Perkin-Elmer Cetus), $0.25 \mathrm{~mm}$ spermidine, and $0.1 \mathrm{ml}$ of $\left[\alpha-{ }^{32} \mathrm{P}\right] \mathrm{dCTP}(3000 \mathrm{Ci} / \mathrm{ml})$ (New England Nuclear) in a volume of $10 \mu$. The PCR products of exon $6(0.5 \mu \mathrm{l})$ were diluted in $5 \mu \mathrm{l}$ of sequencing stop solution $[0.1 \%$ SDS, $20 \mathrm{mM}$ EDTA, $95 \%$ formamide, $0.05 \%$ bromphenol blue (BPB), and $0.05 \%$ xylene cyanol] containing $20 \mathrm{~mm} \mathrm{NaOH}$. The samples were denatured at $95^{\circ} \mathrm{C}$ for $3 \mathrm{~min}$ and kept on ice until loaded on a $50 \%$ Hydrolink-MDE polymer (AT Biochem), electrophoresed in $0.5 \times \mathrm{TBE}$ buffer at $17 \mathrm{~W}$ constant wattage for 16 hr. After electrophoresis, gels were transferred to Whatman $3 \mathrm{M}$ paper and dried on vacuum slab dryers. Autoradiography was performed with Kodak X-Omat AR film for 4-8 hr at room temperature.

\section{Allele-specific oligonucleotide hybridization assay}

Twenty microliters of PCR-amplified (using primers 5451 and 5392) cDNA and DNA from Rat 2 cells, newborn kidney, and various adult rat tissues was fractionated on $10 \%$ native polyacrylamide gels, denatured with $\mathrm{NaOH}$, neutralized, and blotted onto nylon filters (Nytran, Schleicher \& Schuell) in $6 \times$ standard saline citrate (SSC) for $4 \mathrm{hr}$ to overnight. The filters were baked for $1 \mathrm{hr}$, prehybridized for $2 \mathrm{hr}$ at $54^{\circ} \mathrm{C}$ in $3 \mathrm{M}$ tetramethyl ammonium chloride, $50 \mathrm{~mm}$ Tris- $\mathrm{HCl}$ (pH 7.5), 2 mM EDTA, 
$0.3 \%$ SDS, $5 \times$ Denhart's solution, and $100 \mu \mathrm{g} / \mathrm{ml}$ of sonicated salmon testis DNA. Allele-specific oligonucleotides 5495 (CTC) and 5496 (CCC) were end-labeled using T4 polynucleotide kinase [New England Biolabs (NEB)] and $\left[\gamma_{-}{ }^{32} \mathrm{P}\right]$ ATP $\mid 6000$ $\mathrm{Ci} / \mathrm{ml}, \mathrm{NEN}$ ) to a specific activity of $\sim 4 \times 10^{6} \mathrm{cpm} / \mathrm{pmole}$. Probes were purified free of the $\left[\gamma^{-32} \mathrm{P}\right]$ ATP by column chromatography using P10 BioGel (Bio-Rad) columns. Probe $\left(1 \times 10^{7}\right.$ $\mathrm{cpm} / \mathrm{ml}$ ) was added to the prehybridization buffer and hybridized for $2 \mathrm{hr}$ at $54^{\circ} \mathrm{C}$. Blots were washed for $30 \mathrm{~min}$ by pouring $6 \times$ SSC, $0.75 \%$ SDS, at $1^{\circ}$ below the respective melting temperature of $56^{\circ} \mathrm{C}$ and $58^{\circ} \mathrm{C}$ for oligonucleotides 5495 and 5496. The blots were exposed to XAR film at $-70^{\circ} \mathrm{C}$ with an intensifying screen for $1-4 \mathrm{hr}$. Prior to hybridization of the same filter with a new probe, the previously used probe was stripped off the blot by pouring $6 \times \mathrm{SSC}, 0.5 \% \mathrm{SDS}$, at $60^{\circ} \mathrm{C}$ on it, followed by a rinse with $6 \times$ SSC. The blot was exposed overnight to XAR film to verify complete removal of the radioactive probe.

\section{LORS assay using MnlI}

Fifteen-microliter aliquots of PCR products generated from DNA (92- to 102-bp exon 6 fragments) or cDNA $(92-, 102-$, or 277-bp fragments) using primer combinations 5451 plus 5449 , 5451 plus 5392 , or 5344 plus 4585 , respectively, were digested with 5 units of MnlI (NEB), $2 \mu \mathrm{l}$ of $10 \times \mathrm{MnII}$ buffer in a total volume of $20 \mu \mathrm{l}$ overnight at $37^{\circ} \mathrm{C}$. Tubes set up in parallel for each sample with all the ingredients minus the enzyme served as undigested controls. Two microliters of gel sample buffer $10.25 \%$ BPB in $15 \%$ Ficoll) was added to each tube, the sample was fractionated by electrophoresis on $10 \%$ native polyacrylamide gels (19:1 acrylamide/bis) for 500 volt hours in $1 \times \mathrm{TBE}$ $(0.89 \mathrm{M}$ Tris at $\mathrm{pH} 8.3,0.09 \mathrm{M}$ borate, $0.2 \mathrm{M}$ EDTA). Following electrophoresis, the gels were stained in $1 \times \mathrm{TBE}$ containing 0.1 $\mu \mathrm{g} / \mathrm{ml}$ of ethidium bromide. The two marker lanes were loaded with $0.5 \mu \mathrm{g}$ of $\phi_{x}$ cut with HaeIII (NEB), or pBR322 cut with MspI (NEB). PCR fragments generated from plasmid WT1-T or WT1-C that contained the B2 region (described above) of WT1 with either a $\mathrm{T}$ or a $\mathrm{C}$ at nucleotide 839 served as experimental controls.

\section{In vitro transcription}

The 731-bp DNA fragments of rat WT1 containing T/C-839 were obtained by PCR amplification of rat kidney cDNA 0.5 $\mu \mathrm{g})$ using primers 4581 and 4585 . The PCR fragments were then cloned in the PCR-cloning/sequencing vector pT7Blue (Novagen). WT1 PRO and LEU clones were identified by oligonucleotide hybridization and confirmed by direct sequencing. The cDNA clones with antisense orientation to the $\mathrm{T} 7$ promoter were used as templates for in vitro transcription. One microgram of plasmid DNA was linearized at its $3^{\prime}$ end with BamHI and transcribed using $\mathrm{T} 7$ polymerase in a $20-\mu \mathrm{l}$ reaction (Ambion, Inc.) under the conditions specified by the manufacturer. The reaction was carried out at $37^{\circ} \mathrm{C}$ for $16 \mathrm{hr}$ in $40 \mathrm{~mm}$ Tris$\mathrm{HCl}(\mathrm{pH} 9.25), 6 \mathrm{mM} \mathrm{MgCl}, 2 \mathrm{mM}$ spermidine, $200 \mu \mathrm{g} / \mathrm{ml}$ of BSA, $10 \mathrm{mM}$ DTT, $200 \mu \mathrm{M}$ each ATP, CTP, GTP, and UTP, and 12 units of T7 RNA polymerase. Following the reaction, the template DNA was degraded by adding $1 \mu \mathrm{l}$ of $2 \mathrm{U} / \mathrm{ml} \mathrm{RQ1}$ DNase and incubating for $15 \mathrm{~min}$ at $37^{\circ} \mathrm{C}$. The reaction was terminated by the addition of $30 \mu$ lof RNase free $\mathrm{dH}_{2} \mathrm{O}$ and 25 $\mu l$ of $7.5 \mathrm{M} \mathrm{LiCl}$ precipitation solution. The contents were mixed thoroughly and chilled for $30 \mathrm{~min}$ at $-20^{\circ} \mathrm{C}$. The RNA was pelleted by centrifugation, washed with $70 \%$ ethanol, and resuspended in diethylpyrocarbonate-treated (DEPC) water. The transcript was purified by a centrifugation wash in a Centricon 30 column (Amicon) to remove the unincorporated nucleotides, according to manufacturer's instructions. The RNA was reprecipitated with ethanol and dissolved in DEPC-treated water, and its concentration was estimated by spectrophotometric analysis at $260 \mathrm{~nm}$ and electrophoresis in glycerol-agarose gels.

\section{RNase protection assay}

The RNase protection assay was performed by standard methods (Myers et al. 1985). A ${ }^{32} \mathrm{P}$-labeled antisense RNA probe was synthesized from linearized WT1 (B2) wild-type DNA template $\left(\mathrm{T}^{839}\right)$ with the $\mathrm{T} 7$ transcription system. Total RNA $(40-50 \mu \mathrm{g})$ and $5.0 \times 10^{5} \mathrm{cpm}$ of ${ }^{32} \mathrm{P}$-labeled RNA probe were dissolved in 30 $\mu \mathrm{l}$ of $80 \%$ deionized formamide, $40 \mathrm{~mm}$ PIPES at $\mathrm{pH} 6.0,0.4 \mathrm{M}$ $\mathrm{NaCl}$, and $1.0 \mathrm{~mm}$ EDTA, denatured at $80^{\circ} \mathrm{C}$ for $5 \mathrm{~min}$ and annealed for $12-14 \mathrm{hr}$ at $45^{\circ} \mathrm{C}$. Digestion of the hybridization mixture was performed by the addition of $300 \mu \mathrm{l}$ of RNase digestion buffer $(300 \mathrm{~mm} \mathrm{NaCl}, 5 \mathrm{~mm}$ EDTA, $10 \mathrm{~mm}$ Tris- $\mathrm{HCl}$ at $\mathrm{pH} 7.5$ ) containing $40 \mu \mathrm{g} / \mathrm{ml}$ of RNase A (Sigma) and $700 \mathrm{U} / \mathrm{ml}$ RNase T1 (BRL). After $60 \mathrm{~min}$ at $37^{\circ} \mathrm{C}$, the digestion was terminated by the addition of $20 \mu \mathrm{l}$ of $10 \%$ SDS, and $5 \mu \mathrm{g}$ of proteinase $\mathrm{K}$ (Sigma) and further incubated for $15 \mathrm{~min}$ at $37^{\circ} \mathrm{C}$. Twenty micrograms of carrier tRNA was then added, followed by phenol-chloroform extraction and ethanol precipitation. The precipitated RNA-RNA hybrids and digestion products were washed twice with $70 \%$ ethanol and analyzed by electrophoresis in $6 \%$ urea-acrylamide gel followed by autoradiography.

\section{Human WT1, PRO-264 construction}

In vitro mutagenesis of the WT1 cDNA was carried out using the single-stranded mutagenesis kit from Bio-Rad (Kunkel 1985). Briefly, single-stranded, uracil-containing phagemid DNA was isolated from plasmid pGEM-7Zf ${ }^{+}-\mathrm{WTl}$ (Morris et al. 1991), which contains the entire WT1 protein-coding sequence. The mutagenic oligonucleotide primer (HUM), was annealed, complementary DNA was synthesized, and the DNA was transformed into DH5 $\alpha$ cells. The mutagenesis resulted in a substitution of a proline for leucine at amino acid 264 of the WT1 protein. The mutation was verified in two independent clones by dideoxy DNA sequencing and mutant derivatives subcloned into the $\mathrm{pCB}^{+}$expression vector (Madden et al. 1991), which drives the expression of the WT1 alleles using the CMV immediate early promoter.

\section{Screening of the human libraries for edited forms of WT1}

cDNA libraries from human brain (courtesy of Marc Montminy, Salk Institute, La Jolla, CA), B cells, (courtesy of Glen Evans, Salk Institute), and testis (Stratagene) in Lambda Zap were screened for the presence of the CTC and CCC forms of WT1. Oligonucleotide primers 5344 and 5655 were used to amplify a 277-bp human WT1 fragment spanning nucleotides 1033-1310 of human LK15 cDNA sequences under standard conditions at an annealing temperature of $60^{\circ} \mathrm{C}$. The PCR-derived fragment was analyzed by MnlI assay, as described previously for rat WT1, for the detection of human WT LEU or PRO at nucleotide 1222.

\section{Cell culture}

NIH 3T3 cells were maintained in Dulbecco's modified Eagle medium (high glucose) supplemented with $200 \mathrm{~mm}$ L-glutamine and $10 \%$ calf serum. COS- 1 cells were maintained in Iscove's modified Eagle's medium supplemented with $200 \mathrm{~mm}$ L-glutamine and $10 \%$ fetal bovine serum. 


\section{DNA extraction}

Genomic DNA was prepared from tissues and cell lines using the SDS-proteinase K method (Gross-Bellard et al. 1973). The minced tissue (washed 3 times with $1 \times$ phosphate buffered saline/EDTA, $0.5 \%$ ) or the cell pellet was suspended in $10 \mathrm{~mm}$ Tris (pH 7.4), $100 \mathrm{~mm} \mathrm{NaCl} .1 \mathrm{mM}$ EDTA, $1 \%$ SDS, and 100 $\mathrm{mg} / \mathrm{ml}$ proteinase $\mathrm{K}$ overnight at $37^{\circ} \mathrm{C}$. The DNA was then extracted twice with phenol-chloroform, $1 \times$ with chloroform/ isoamyl alcohol (24:1), precipitated with ethanol, washed in $70 \%$ ethanol, spooled on a glass rod, dried, and resuspended in $10 \mathrm{~mm}$ Tris- $\mathrm{Cl}$ at $\mathrm{pH} 7.4$ containing $1 \mathrm{~mm}$ EDTA.

\section{RNA isolation}

Total RNA was isolated from cell pellets or frozen tissues ground in liquid nitrogen by guanidinium isothiocyanate (Chirgwin et al. 1979) and ultracentrifugation through cesium chloride (Glizin et al. 1974).

\section{Acknowledgments}

We thank Tony Hunter, Michael McKeown, Bart Sefton, Walter Eckhart, and Inder Verma for their thoughtful discussions and critical review of this manuscript. This work was supported in part by U.S. Public Health Service grants CA48943 (S.S.), CA57993 (S.S.), CA52009 (F.J.R.), and CA47983 (F.J.R.). This work also received support from the Foundation for Medical Research, Inc. (S.S.), Stern Foundation (S.S.), March of Dimes Birth Defects Foundation (S.S.), W.W. Smith Charitable Trust (F.J.R.), the Hansen Memorial Foundation (F.J.R.) and the Mary A.H. Rumsey Foundation (F.J.R.). F.J.R. is a Pew Scholar in the Biomedical Sciences.

The publication costs of this article were defrayed in part by payment of page charges. This article must therefore be hereby marked "advertisement" in accordance with 18 USC section 1734 solely to indicate this fact.

\section{References}

Backus, J.W. and H.C. Smith. 1991. Apolipoprotein B mRNA sequences $3^{\prime}$ of the editing site are necessary and sufficient for editing and editosome assembly. Nucleic Acids Res. 19: $6781-6786$.

Bickmore, W.A., K. Oghene, M.H. Little, A. Seawright, V. van Heyningen, and N.D. Hastie. 1992. Modulation of DNA binding specificity by alternative splicing of the Wilm's Tumor WT1 gene transcript. Science 257: 235-237.

Burnashev, N., H. Monyer, P.H. Seeburg, and B. Sakmann. 1992a. Divalent ion permeability of AMPA receptor channel is dominated by the edited form of a single subunit. Neuron 8: $189-198$.

Burnashev, N., A. Khodorova, P. Jonas, P.J. Helm, W. Wisden, H. Monyer, P.H. Seeburg, and B. Sakmann. 1992b. Calciumpermeable AMPA/kainate receptors in fusiform cerebellar glial cells. Science 256: 1566-1570.

Call, K.M., T. Glaser, C.Y. Ito, A.J. Buckler, J. Pelletier, D.A. Haber, E.A. Rose, A. Kral, H. Yeger, W.H. Lewis, C. Jones, and D.E. Housman. 1990. Isolation and characterization of a zinc finger polypeptide gene at the human chromosome 11 Wilms' tumor locus. Cell 60: 509-520.

Cattaneo, R. 1991. Different types of messenger RNA editing. Annu. Rev. Genet. 25: 71-88.

Chan, L. 1993. RNA editing: Exploring one mode with apolipoprotein B mRNA. BioEssays 15: 33-41.

Chirgwin, J.M., A.E. Przybyla, R.J. MacDonald, and W.J. Rutter.
1979. Isolation of biologically active ribonucleic acid from sources enriched in ribonuclease. Biochemistry 18: 5294 5299.

De La Torre, J.C., C. Giachetti, B.L. Semler, and J.J. Holland. 1992. High frequency of single-base transitions and extreme frequency of precise multiple-base reversion mutations in poliovirus. Proc. Natl. Acad. Sci. 89: 2531-2535.

Gashler, A.L., D.T. Bonthron, S.L. Madden, F.J. Rauscher III, T. Collins, and V.P. Sukhatme. 1992. Human platelet-derived growth factor A chain is transcriptionally repressed by the Wilms tumor suppressor WT1. Proc. Natl. Acad. Sci. 89: 10984-10988.

Gessler, M., A. Poustka, W. Cavanee, R.L. Neve, S.H. Orkin, and G.A.P. Bruns. 1990. Homozygous deletion in Wilms' tumors of a zinc-finger gene identified by chromosome jumping. Nature 343: 774-778.

Glizin, V., R. Crkevngakov, and C. Byns. 1974. Ribonucleic acid isolated by cesium chloride centrifugation. Biochemistry 13: $2633-2637$.

Goff, S.P. 1990. Retroviral reverse transcriptase: Synthesis, structure and function. I Acquir. Immune Defic. Syndr. 3: 817-831.

Gorman, C.M., L.F. Moffat, and B.H. Howard. 1982. Recombinant genomes which express chloramphenicol acetyltransferase in mammalian cells. Mol. Cell. Biol. 2: 1044-1051.

Gross-Bellard, M., P. Oudet, and P. Chambon. 1973. Isolation of high molecular weight DNA from mammalian cells. Eur. $J$. Biochem. 36: 32-38.

Haber, D.A. and A.J. Buckler. 1992. WT1: A novel tumor suppressor gene inactivated in Wilms' tumor. New Biol. 4: 97 106.

Haber, D.A. and D.E. Housman. 1992. The genetics of Wilms' tumor. Adv. Cancer Res. 59: 41-68.

Haber, D.A., R.L. Sohn, A.J. Buckler, J. Pelletier, K.M. Call, and D.E. Housman. 1991. Alternative splicing and genomic structure of the Wilms' tumor gene WT1. Proc. Natl. Acad. Sci. 88: 9618-9622.

Kohler, M., N. Burnashev, B. Sakmann, and P.H. Seeburg. 1993. Determinants of $\mathrm{Ca}^{2+}$ permeability in both TM1 and TM2 of high affinity kainate receptor channels: Diversity by RNA editing. Neuron 10: 491-500.

Kunkel, T.A. 1985. Rapid and efficient site-specific mutagenesis without phenotypic selection. Proc. Natl. Acad. Sci. 82: $488-492$.

Kunkel, T.A., R.D. Sabatino, and R.A. Bambara. 1987. Exonucleolytic proofreading by calf thymus DNA polymerase $\delta$. Proc. Natl. Acad. Sci. 84: 4865-4869.

Lau, P.P., W. Xiong, H.-J. Zhu, S.-H. Chen, and L. Chan. 1991. Apolipoprotein B mRNA editing is an intranuclear event that occurs posttranscriptionally coincident with splicing and polyadenylation. J. Biol. Chem. 266: 20550-20554.

Madden, S.L., D.M. Cook, J.F. Morris, A. Gashler, V.P. Sukhatme, and F.J. Rauscher III. 1991. Transcriptional repression mediated by the WT1 Wilms tumor gene product. Science 253: 1550-1553.

Mattila, P., J. Korpela, T. Tenkanen, and K. Pitkanen. 1991. Fidelity of DNA synthesis by the Thermococcus litoralis DNA polymerase-an extremely heat stable enzyme with proofreading activity. Nucleic Acids Res. 19: 4967-4973.

Mitchell, P.J. and R. Tjian. 1989. Transcriptional regulation in mammalian cells by sequence-specific DNA binding proteins. Science 245: 371-378.

Morris, J.F., S.L. Madden, O.E. Tournay, D.M. Cook, V.P. Sukhatme, and F.J. Rauscher III. 1991. Characterization of the zinc finger protein encoded by the WT1 Wilms' tumor locus. Oncogene 6: 2339-2348. 
Myers, R.M., Z. Larin, and T. Maniatis. 1985. Detection of single base substitutions by ribonuclease cleavage at mismatches in RNA:DNA duplexes. Science 230: 1242-1246.

Navaratnam, N., D. Patel, R.R. Shah, J.C. Greeve, L.M. Powell, T.J. Knott, and J. Scott. 1991. An additional site is present in apolipoprotein B mRNA. Nucleic Acids Res. 19: 1741-1744.

Orita, M., H. Iwahana, H. Kanazawa, K. Hayashi, and T. Sekiya. 1989a. Detection of polymorphisms of human DNA by gel electrophoresis as single-strand conformation polymorphisms. Proc. Natl. Acad. Sci. 86: 2766-2700.

Orita, M., Y. Suzuki, T. Sekiya, and K. Hayashi. 1989b. Rapid and sensitive detection of point mutations and DNA polymorphisms using the polymerase chain reaction. Genomics 5: 874-879.

Pelletier, J., M. Schalling, A.J. Buckler, A. Rogers, D.A. Haber, and D. Housman. 1991. Expression of the Wilms' tumor gene WT1 in the murine urogenital system. Genes \& Dev. 5: 1345-1356.

Powell, L.M., S.C. Wallis, R.J. Pease, Y.H. Edwards, T.J. Knott, and J. Scott. 1987. A novel form of tissue-specific RNA processing produces apolipoprotein-B48 in intestine. Cell 50: $831-840$.

Rauscher III, F.J., J.F. Morris, O.E. Tournay, D.M. Cook, and T. Curran. 1990. Binding of the Wilms' tumor locus zinc finger protein to the EGR-1 consensus sequence. Science 250: 1259-1262.

Saiki, R.K., D.H. Gelfand, S. Stoffel, S.J. Sharf, R. Higuchi, G.T. Horn, K.B. Mullis, and H.A. Erlich. 1988. Primer-directed enzymatic amplification of DNA with a thermostable DNA polymerase. Science 239: 487-491.

Schuster, W., R. Hiesel, B. Wissinger, and A. Brennicke. 1990. RNA editing in the cytochrome b locus of the higher plant Oenothera berteriana includes a $\mathrm{U}$ to $\mathrm{C}$ transition. Mol. Cell. Biol. 10: 2428-2431.

Shah, R.R., T.J. Knott, J.E. Legros, N. Navaratnam, J.C. Greeve, and J. Scott. 1991. Sequence requirements for the editing of apolipoprotein B mRNA. J. Biol. Chem. 266: 16301-16304.

Sharma, P.M., X. Yang, M. Bowman, V. Roberts, and S. Sukumar. 1992. Molecular cloning of rat Wilms' tumor complementary DNA and a study of messenger RNA expression in the urogenital system and the brain. Cancer Res. 52: 64076412.

Slater, R.M. and M.M. Mannen. 1992. Cytogenetics and molecular genetics of Wilms' tumor of childhood. Cancer Genet. Cytogenet. 61: 111-121.

Spaete, R.R. and E.S. Mocarski. 1985 Regulation of cytomegalovirus gene expression: Alpha and beta promoters are trans activated by viral functions in permissive human fibroblasts. I. Virol. 56: 135-143.

Teng, B.B., D.D. Black, and N.O. Davidson. 1990. Apolipoprotein B messenger RNA editing is developmentally regulated in pig small intestine: Nucleotide comparison of apolipoprotein B editing regions in five species. Biochem. Biophys. Res. Commun. 173: 74-80.

Teng, B.B., C.F. Burant, and N.O. Davidson. 1993. Molecular cloning of an apoliprotein B messenger RNA editing protein. Science 260: 1816-1821.

Wang, Z.- Y., S.L. Madden, T.F. Deuel, and F.J. Rauscher III. 1992. The Wilms' tumor gene product, WT1, represses transcription of the platelet-derived growth factor A-chain gene. I. Biol. Chem. 267: 21999-22002.

Wang, Z.-Y., Q.-Q. Qiu, and T.F. Deuel. 1993. The Wilms' tumor gene product WTl activates or suppresses transcription through separate functional domains. J. Biol. Chem. 268: 9172-9175.

Werner, H., G.G. Re, I.A. Drummond, V.P. Sukhatme, F.J.
Rauscher III, D.A. Sens, A.J. Garvin, D. LeRoith, and C.T. Roberts Jr. 1993. Increased expression of the insulin-like growth factor I receptor gene, IGF1R, in Wilms tumor is correlated with modulation of $I G F 1 R$ promoter activity by the WT1 Wilms tumor gene product. Proc. Natl. Acad. Sci. 90: $5828-5832$.

Winter, E., F. Yamamoto, C. Almoguera, and M. Perucho. 1985. A method to detect and characterize point mutations in transcribed genes: Amplification and overexpression of the mutant c-Ki-ras allele in human tumor cells. Proc. Natl. Acad. Sci. 82: 7575-7579.

Wissinger, B., A. Brennicke, and W. Schuster. 1992. Regenerating good sense: RNA editing and trans splicing in plant mitochondria. Trends Genet. 8: 322-328.

Wu, J.H., C.F. Semenkovich, S.-H. Chen, W.-H. Li, and L. Chan. 1990. Apolipoprotein B mRNA editing: Validation of a sensitive assay and developmental biology of RNA editing in the rat. J. Biol. Chem. 265: 12312-12316. 


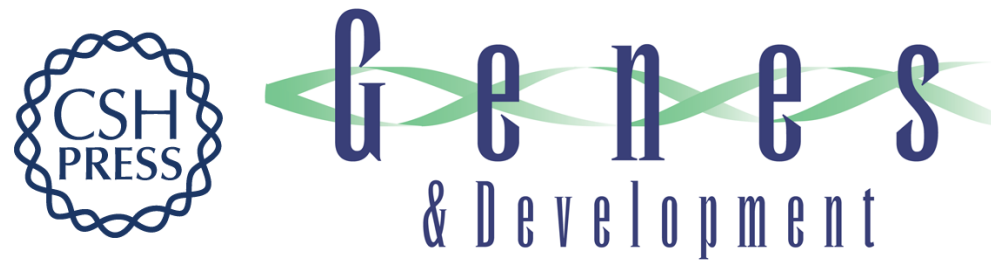

\section{RNA editing in the Wilms' tumor susceptibility gene, WT1.}

P M Sharma, M Bowman, S L Madden, et al.

Genes Dev. 1994, 8:

Access the most recent version at doi:10.1101/gad.8.6.720

References This article cites 46 articles, 25 of which can be accessed free at: http://genesdev.cshlp.org/content/8/6/720.full.html\#ref-list-1

\section{License}

Email Alerting

Receive free email alerts when new articles cite this article - sign up in the box at the top Service right corner of the article or click here.

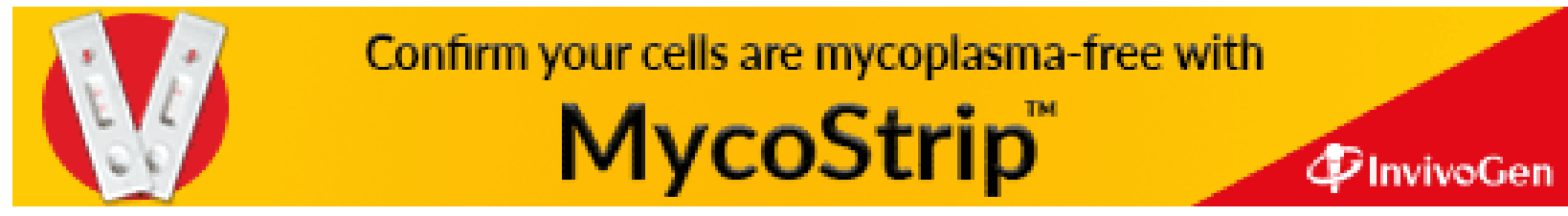

